\title{
PEMBIASAAN SEBAGAI BASIS \\ PENANAMAN NILAI-NILAI AKHLAK REMAJA
}

\author{
Oleh: Abdul Rohman \\ IAIN Walisongo Semarang
}

\begin{abstract}
Abstrak
Untuk membentuk manusia yang memiliki moral baik (good moral person) bukanlah sesuatu yang tiba-tiba. Ia memerlukan suatu proses panjang yang memerlukan tahap-tahap, ia membutuhkan suatu kondisi yang memungkinkan seorang individu berperilaku sebagai sosok yang memiliki moral yang diharapkan (moral action). Karenanya, ia memerlukan suatu pembiasaan (babituation) yang dalam pembiasaan itu secara implisit terdapat adanya keteladanan (modelling). Karena itu diperlukan kerjasama secara integratif dari semua komponen baik di sekolah, keluarga maupun masyarakat untuk menciptakan lingkungan yang mampu membiasakan perilaku anak. Secara formal, dalam proses pembelajaran bisa dipertimbangkan beberapa model pembelajaran yang bisa dipilih sesuai dengan situasi yang melingkupinya, yaitu: model konsiderasi, pembentukan rasional, klarifikasi nilai, pengembangan moral kognitif, model non-direktif.
\end{abstract}

Kata Kunci: Akhlak, Moral, Internalisasi, Pembiasaan, Modelling 


\section{A. Pendahuluan}

Moralitas bangsa akhir-akhir ini menjadi semakin bermasalah. $\mathrm{Hal}$ ini diindikasikan antara lain: tingginya angka korupsi kolusi dan nepotisme (KKN), merebaknya kasus penyalahgunaan narkoba, pergaulan bebas, kriminalitas, kekerasan. Di samping itu, kesopanan, sifat ramah, tenggang rasa, rendah hati, suka menolong, solidari-tas sosial yang ini merupakan jati diri bangsa selama berabad-abad seolaholah kurang begitu melekat secara kuat dalam diri mereka. ${ }^{1}$ Demikian juga meningkatnya perilaku kekerasan terhadap orang lain yang berbeda kepercayaan, berbeda suku, berbeda golongan, makin semrawutnya lalu lintas, makin rusaknya lingkungan hidup, merupakan indikator lain dari problem moralitas.

Apakah realitas ini mengindikasikan bahwa ada persoalan dengan pendidikan di Indonesia. Apakah bisa dinyatakan bahwa sistem pendidikan kita belum bisa mengantarkan peserta didik yang memiliki moralitas yang baik, memiliki karakter yang kuat, akhlak atau budi pekerti yang luhur. Kalau jawabannya iya, di mana letak kesalahannya. Kurikulum sebagai sebuah dokumen (written curriculum), menunjukkan bahwa ia sudah direncanakan dengan baik. ${ }^{2}$ Tetapi memang sebaik-baik written curriculum itu disusun, efektivitasnya akan ditentukan pada saat implementasinya ( actual curriculum). Persoalan moralitas atau budi pekerti atau karakter atau akhlak, bila dilihat dalam perspektif Bloom (1976) yang membagi domain tujuan pendidikan atas tiga hal, yakni kognitif, afektif dan psikomotorik, maka persoalan-persoalan tadi adalah persoalan yang lebih menyangkut pada domain afektif.

Realitas di lapangan menunjukkan bahwa sistem pembelajaran dilaksanakan kurang proporsional dalam sentuhan domain. Dalam

1 Zubaedi. "Memperkuat Dimensi Pendidikan Moral: Kata Pengantar" dalam Mawardi Lubis. Evaluasi Pendidikan Nilai. (Yogjakarta: Pustaka Pelajar, 2009), hlm. 5

${ }^{2}$ Tujuan pendidikan nasional (Undang-undang SISDIKNAS Nomor 20 tahun 2003, bab II pasal 3) yang ini menjadi entry point dari semua rumusan tujuan institusional semua sekolah dan madrasah secara eksplisit merumuskan bahwa "Pendidikan nasional ... bertujuan untuk berkembangnya potensi peserta didik agar menjadi manusia yang beriman dan bertaqwa kepada Tuhan Yang Maha Esa, berakhlak mulia, sehat, berilmu, cakap, kreatif, mandiri, dan menjadi warga negara yang demokratis serta bertanggung jawab". 
taksonomi Bloom tersebut, maka kognisi itu lebih dominan. ${ }^{3}$ Kognisi memang ikut memberikan kontribusi pada pembentukan afeksi, tetapi sumbangannya kecil. ${ }^{4}$

Pembelajaran afeksi kurang mendapatkan proporsi yang cukup, bahkan sering terabaikan. ${ }^{5}$ Padahal, bila dicermati rumusan tujuan pendidikan dalam Undang-undang SISDIKNAS Nomor 20 tahun 2003 Bab II pasal 3, rumusan tersebut sebenarnya lebih menekankan pada aspek afektif. Azra menyatakan bahwa pembelajaran lebih banyak diorientasikan pada aspek kognitif, pendekatan dalam pembelajaran pendidikan agama cenderung bertumpu pada aspek kognisi daripada aspek afeksi. ${ }^{6}$ Pembelajaran PAI di sekolahsekolah atau madrasah-madrasah lebih bersifat "transmission rather than transformation". Aspek afeksi sebenarnya memainkan peran yang sangat penting dalam kehidupan manusia, terutama dalam pembuatan keputusan, persepsi, interaksi dan komunikasi serta intelegensi. ${ }^{7}$ Berdasarkan riset, kebahagiaan (baca: keberhasilan) seseorang itu lebih banyak dipengaruhi oleh aspek mental. Persoalan mental adalah persoalan afeksi, yang secara visual bisa dilihat pada gambar berikut ini:

${ }^{3}$ Menurut Hadjar (2006: 5), terabaikannya faktor afektif diantaranya dikarenakan: (1) ranah afektif sulit dide $\square$ nisikan dan diukur (2) terbatasnya alat evaluasi untuk mengu-kurnya (3) keengganan untuk memberikan nilai pada aspek afektif karena terkait dengan masalah validitas dan reliabilitasnya (4) kesulitan menentukan standard perilaku yang mencerminkan ranah afektif (5) sedikitnya konsekuensi langsung yang mencerminkan dalam perilaku afektif.

${ }^{4}$ Krathwohl, David R. Taxonomy of Educational Objective Book II: Affective Domain. (London: Longman Group, 1973), hlm. 20

${ }^{5}$ Secara umum, setiap Mata Pelajaran (Mapel) di sekolah atau madrasah memiliki aksentuasi yang berbeda pada tiga ranah tersebut. Tetapi semua Mapel memiliki tanggung jawab untuk mem $\neg$ backup semua ranah tersebut. Kelompok pelajaran Agama dan akhlak mulia serta Kewarganegaraan dan Kepribadian, adalah dua kelompok mata pelajaran yang lebih menekankan aspek afeksi daripada dua aspek lainnya, kognisi dan psikomotor.

${ }^{6}$ Azra, Azyumardi. Paradigma Baru Pendidikan Nasional: Rekonstruksi dan Demokratisasi. (Jakarta: Kompas, 2002), hlm. 178

${ }^{7}$ Mas'ud, Abdurrahman. Menggagas Format Pendidikan Non Dikotomik: Humanisme Religius sebagai Paradigma Pendidikan Islam. (Yogjakarta: Gama Media, 2002), hlm. 212. 
Abdul Rohman

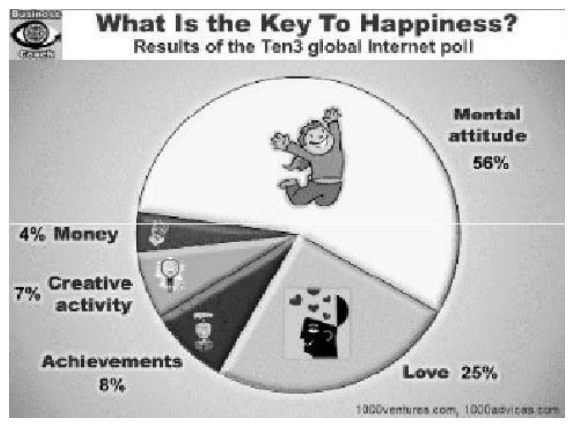

Martin Luther King menyatakan bahwa "We must remember that intelligence is not enough. Intelligence plus character-that is the goal of true education". " Demikian juga Ki Hajar Dewantara menyatakan bahwa:

Maksud pendidikan adalah sempurnanya hidup manusia sehingga bisa memenuhi segala keperluan hidup lahir batin. Yang kita dapat dari kodrat alam...

Pengetahuan, kepandaian janganlah dianggap maksud dan tujuan, tetapi alat, perkakas, lain tidak.

Bunganya, yang kelak akan jadi buah, itulah yang harus diutamakan.

Buahnya pendidikan, yaitu matangnya jiwa, yang akan dapat mewujudkan hidup dan penghidupan yang tertib dan suci dan manfaat bagi orang lain

Di samping itu, ada kenyataan lain bahwa implementasi pembelajaran di sekolah ataupun madrasah cenderung terpisah antara satu Mapel dengan Mapel lainnya, termasuk Mapel PAI, juga PPKN. Bahkan seringkali terjadi pembelajaran PAI dilakukan dengan tidak melibatkan komponen-komponen lain terutama orang tua dan masyarakat, padahal jumlah jam Mapel PAI hanya dua jam seminggu sehingga pembelajaran hanya mengejar aspek kognitif saja. Penanaman nilai-nilai akhlak memerlukan tanggung jawab bersama semua komponen: sekolah, masyarakat, orang tua. Oladipo menyatakan bahwa "moral education was responsible for all. Because each child from birth belongs to significant group, so family members, friends, relatives, teachers and

${ }^{8}$ www.freedomforum.org/publications/ $\square$ rst/.../b.13.charactered.pdf, 2012. 
administrators play a major role in the formation of the character of each child". 9

Dalam kerangka penanaman nilai akhlak, yang masuk dalam bingkai afeksi, pembiasaan (babituation) memegang peranan yang sangat penting. Sebab nilai-nilai (values) tidak bisa diajarkan, nilainilai hanya bisa dipraktekkan; maka sebagai pendidik, guru harus bisa menjadikan keteladanan bagi muridnya, sehingga pendidikan dilakukan dengan "aura pribadi".

\section{B. Karakteristik Remaja \& Akhlak}

\section{Karakteristik Remaja}

Remaja atau sering dikenal dengan adolescence berasal dari kata latin adoloecere atau adolescentia yang berarti tumbuh atau tumbuh menjdi dewasa. Istilah adolescence mempunyai arti luas, mencak-up kematangan mental, emosional, sosial dan fisik oleh Hurlock. Masa remaja pada umumnya mulai saat anak secara seksual menjadi matang dan berakhir saat ia mencapai usia matang secara hukum.

Masa remaja biasanya berada di antara usia 12/13 -20/21 tahun, yang secara psikologis, dicirikan dengan sebagai berikut:
a. Periode yang penting
b. Periode peralihan
c. Periode perubahan
d. Usia bermasalah
e. Masa mencari identitas
f. Usia yang menimbulkan ketakutan
g. Masa yang tidak realistik
h. Ambang masa dewasa

Secara moral, perkembangan masa remaja menurut Kohlberg memiliki ciri-ciri sebagai masa conventional level (10-14 tahun) dan post conventional level (14-22 tahun), yaitu:

Masa konvensional: tahapan kepatuhan yang dasarnya hanya seke-

9 Oladipo, S.E.. "Moral Education of the Child: Whose Responsibility?", J Sec Sei, 2009, 20(2), pp. 149-156, hlm. 149. 
dar membina harapan dan/atau nilai-nilai yang diharapkan seseorang, kelompok, bangsa sehingga keputuhan hanya berdasar atas intert personal concordance (sebagai anak baik dan manis dalam pujian) dan level law and order orientation (sesuai pesan masyarakat); sedangkan post conventional level, yang sudah memiliki dasar kepatuhan yang jelas, punya prinsip atau nilai moral tertentu yang menjadi landasannya.

Secara psiko-sosial, perkembangan individu, termasuk remaja, banyak dibentuk melalui imitasi, identifi kasi, sugesti, simpati, empati. ${ }^{10}$ Imitasi yaitu meniru sikap, perilaku, gaya, cara berpikir, penampilan, ketrampilan, kemampuan orang lain, yang biasanya didahului dengan penerimaan, penghormatan, pengaguman pada sesuatu yang hendak ditiru. Identifi kasi yaitu imitasi yang mendalam sehingga menjadi sama dengan pihak lain secara disengaja maupun tidak disengaja. Sugesti merupakan usaha mempengaruhi seseorang atas suatu pandangan, pemahaman, sikap, dan lain-lain ketika yang menerima sugesti dalam keadaan tidak berpikir rasional karena diberi sugesti oleh orang yang dikagumi, dihormati, berwibawa, karismatik, pemuka agama, penguasa, golongan mayoritas, dan lain-lain. Simpati yaitu ketertarikan seseorang kepada orang lain yang seolah-olah merasakan perasaan orang lain. Empati yaitu rasa simpati yang sangat mendalam yang mampu memberikan pengaruh pada kejiwaan seseorang.

\section{Karakteristik Akhlak}

\section{a. Pengertian Akhlak}

Secara etimologis, akblak berasal dari bahasa arab, merupakan bentuk jamak dari kata kbuluk, yang berarti perangai, tingkah laku, atau tabiat. ${ }^{11}$ Secara terminologi, akhlak berarti tingkah laku seseorang yang didorong oleh suatu keinginan secara sadar untuk melakukan suatu perbuatan yang baik Tiga pakar di bidang akhlak yaitu Ibnu Miskawaih, al-Ghazali, Ahmad Amin menyatakan bahwa akhlak adalah perangai yang melekat pada diri seseorang yang dapat

\footnotetext{
${ }^{10}$ Gerungan, W.A. Psikologi Sosial. (Jakarta: Rajawali Pers, 1998).

${ }^{11}$ Mubarak, Zakky, dkk. Manusia, Akhlak, Budi Pekerti dan Masyarakat. (Depok: Lembaga Penerbit FE Ul, 2008), hlm. 20
} 
memunculkan perbuatan baik tanpa mempertimbangkan pikiran terlebih dahulu.

Kata akhlak diartikan sebagai suatu tingkah laku, tetapi tingkah laku tersebut harus dilakukan secara berulang-ulang tidak cukup hanya sekali melakukan perbuatan baik, atau hanya sewaktuwaktu saja. ${ }^{12}$ Seseorang dapat dikatakan berakhlak jika timbul dengan sendirinya, didorong oleh motivasi dari dalam diri dan dilakukan tanpa banyak pertimbangan pemikiran apalagi pertimbangan yang sering diulang-ulang, sehingga terkesan sebagai keterpaksaan untuk berbuat. Apabila perbuatan tersebut dilakukan dengan terpaksa bukanlah pencerminan dari akhlak.

Adapun 5 ciri yang terdapat dalam perbuatan akhlak yaitu:

1) Perbuatan akhlak adalah perbuatan yang telah tertanam kuat dalam diri seseorang, sehingga telah menjadi kepribadiannya.

2) Perbuatan akhlak adalah perbuatan yang dilakukan dengan mudah dengan menggunakan tanpa pemikiran.

3) Perbuatan akhlak adalah perbuatan yang timbul dari dalam diri orang yang mengerjakannya, tanpa Ada paksaan atau tekanan dari luar (atas dasar dan keinginan diri sendiri) tanpa paksaan.

4) Perbuatan akhlak adalah perbutan yang di lakukan dengan sesungguhnya, bukan bermain-main atau karena bersandiwara.

5) Sejalan dengan ciri yang ke-4 perbuatan akhlak (khususnya anak yang baik) adalah perbuatan yang dilakukan karena ikhlas semata-mata karena Allah SWT, bukan karena di puji orang atau karena ingin mendapat suatu pujian. ${ }^{13}$

Apa bedanya dengan moral? Moral berasal dari Bahasa Latin "Mores" atau yang sepadan dengan istilah manner, character proper behaviour, yang berarti the differentiation among intentions, dicisions and ac-tions between those that are good (or right) and and bad (or wrong). Piaget dan R.F. Atkitson mengartikan bahwa moral adalah: "view about good and bad, right and wrong, what ought or ought not to do...; a set of belief current in society about character or conduct and what people should try to be or try to do

\footnotetext{
${ }_{12}^{12}$ Bertens, Kees. Etika, (Jakarta: Gramedia Pustaka Utama, 2002), hlm. 26. dan_moral

13 http://wiki.answers.com/Q/Perbezaan_dan_persamaan_antara_akhlak_etika_
} 
...; a set of belief about people and their actions...; a system of conduct assessment which is objectives in that and it reflect the condition of social existence....; rule of conduct actually accepted in society..."

Moralitas adalah sifat moral atau keseluruhan asas dan nilai yang berkenaan dengan baik dan buruk. ${ }^{14}$ Moralitas juga berperan sebagai pengatur dan petunjuk bagi manusia dalam berperilaku agar dapat dikategorikan sebagai manusia yang baik dan dapat menghindari perilaku yang buruk. Standar moral, menurut Velazques, yaitu:

1) Standar moral berkaitan dengan persoalan yang dianggap akan merugikan secara serius atau benar-benar menguntungkan manusia.

2) Standar moral ditetapkan atau diubah oleh keputusan dewan otoritatif tertentu.

3) Standar moral harus lebih diutamakan daripada nilai lain terma-suk kepentingan diri

4) Standar moral berdasarkan pada pertimbangan yang tidak memihak.

5) Standar moral diasosiasikan dengan emosi tertentu dan kosakata tertentu. ${ }^{14}$

Lickona menyatakan bahwa moral akan membentuk suatu karakter seseorang, di mana moralitas mengandung tiga aspek yakni moral knowing, moral feeling, moral behaviour.

Character so conceived has three interrelated parts: moral knowing, moral feeling, and moral behaviour. Good caharacter consists of knowing the good, desiring the good and doing the good---habits of the mind, habits of the heart, and habits of action. All three are necessary for leading a moral life; all rhree make up moral matu-rity. ${ }^{15}$

Ronald Durka menyatakan bahwa ciri-ciri orang yang matang

\footnotetext{
${ }^{14}$ Bertens, etika..., hlm. 7

${ }^{15}$ Velasques, Manuel G. Etika Bisnis, Konsep dan Kasus Business Ethics, Concepts and Cases, terj. Ana Purwaningsih dkk, (Yogjakarta: Kanisius, 2005, hlm. 9-10.

${ }^{16}$ Lickona, Thomas. Educating for Character: How Our Schools Can Teach Respect and Responsibilty. (New York: Bantam Book, 1992), hlm. 51.
} 
secara moral (morally mature person), sebagai berikut:

1. Who holds correct moral position and acts in accord with such position.

2. The knowledge of these do's and dont's right and wrong.

3. The character or will to act in accord with sub 2 .

4. Know best what would or should

5. Mature moral reason.

Aristoteles melukiskan bahwa orang yang bermoral adalah orang yang sosok dirinya menampilkan hal-hal: courage, temperance, liberality, magnificence, bigh mindedness, truthfulness, justice. Higgins dan Giligan (1981) mengemukakan bahwa ciri orang yang bermoral adalah orang yang selalu merasakan adanya moral bases (tuntutan dan keharusan moral) untuk selalu bertanggung jawab terhadap: (1) needs and welfare of the individual and others (2) the involvement and implication of the self and consequences of other (3) intrinsic value of social relationships.

Para fi losof memandang hanya tiga kesempurnaan manusia di dunia ini, yakni kebenaran, kebaikan dan keindahan. Kebenaran merupakan kesempurnaan yang dicapai melalui rasio, kebaikan dicapai melalui moral dengan pertimbangan baik-buruk, keindahan ditangkap melaui indera. Ketiga aspek kesempurnaan ini saling terkait secara hierarkhis. Keindahan merupakan basis untuk memahami kebaikan, kebaikan selanjutnya akan memberikan basis untuk memahami kebenaran.

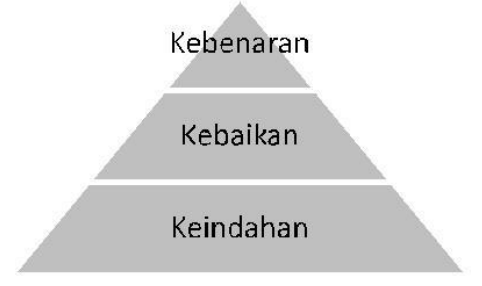

Moral merupakan istilah umum, sedangkan akhlak merupakan terminologi Islam, sehingga Syukur menyebut akhlak dengan istilah moral Islam (islamic morality). Akhlak bersumber dari al-Quran dan alSunnah, sedangkan moral bersumber dari pemikiran manusia dan adat-istiadat. Sedangkan disiplin yang membicarakan prinsip-prinsip 
baik-buruk, apa yang seharusnya dilakukan dan apa yang seharusnya ditinggalkan dinamakan filsafat moral, yang oleh Mudhoffir dinamakan juga dengan Etika. Dengan kata lain, etika adalah salah satu cabang filsafat yang membicarakan tentang nilai-nilai (values). ${ }^{17}$

b. Faktor-faktor yang mempengaruhi Pembentukan Nilai-nilai Akhlak Remaja

Hasil belajar (yang menurut Bloom terdiri dari ranah kognitif, afektif dan psikomotorik) menurut Suryabrata (1993: 249), dipengaruhi oleh banyak hal yang bisa diklasifikasikan ke dalam: (1) Fak-tor dari luar diri pelajar yang meliputi faktor non sosial dan sosial, (2) faktor dari dalam diri pelajar yang meliputi faktor fisiologis dan faktor psikologis. Demikian juga, akhlak sebagai hasil belajar afektif, keberhasilannya dipengaruhi oleh faktor-faktor tersebut.

Secara psiko-sosial, perkembangan individu remaja banyak dibentuk melalui imitasi, identifikasi, sugesti, simpati, empati (Gerungan, 1998). Imitasi yaitu meniru sikap, perilaku, gaya, cara berpikir, penampilan, ketrampilan, kemampuan orang lain, yang biasanya didahului dengan penerimaan, penghormatan, pengaguman pada sesuatu yang hendak ditiru. Identifikasi yaitu imitasi yang mendalam sehingga menjadi sama dengan pihak lain secara disengaja maupun tidak disengaja. Sugesti merupakan mempengaruhi seseorang atas suatu pandangan, pemahaman, sikap dll ketika yang menerima sugesti dalam keadaan tidak berpikir rasional karena diberi sugesti oleh orang yang dikagumi, dihormati, berwibawa, karismatik, pemuka agama, penguasa, golongan mayoritas, dan lain-lain. Simpati yaitu ketertarikan seseorang kepada orang lain yang seolah-olah merasakan perasaan orang lain. Empati yaitu rasa simpati yang sangat mendalam yang mampu memberikan pengaruh pada kejiwaan seseorang.

Anak usia awal sampai usia remaja sebelum mencapai kedewasaan adalah individu yang secara psikologis masih belum matang, yang masih memerlukan banyak treatment dari luar diri. Dalam kon-

${ }^{17}$ Mudhofir, Ali et al. Filsafat IImu. (Yogjakarta: Liberty, 1996), hlm. 19. 
tek ini, hasil belajar (termasuk hasil belajar afektif), lebih banyak dipengaruhi oleh faktor eksternal.

\section{Pembiasaan sebagai Model Penanaman Nilai-nilai}

\section{Akhlak}

Pembiasaan (babituation) merupakan proses pendidikan. Habitu-ation is a function of the number of repetitions of a stimulus. The exact number of repetitions necessary to produce a substantial response decrement varies considerably.

Internalisasi merupakan proses pemantapan dan penanaman keyakinan, sikap, nilai pada diri individu sehingga nilai-nilai tersebut menjadi perilakunya (moral behaviour). Ketika perilaku moral seseorang telah berubah, maka bisa dikatakan nilai-nilai itu sudah tertatamkan dalam dirinya, sebagaimana definisi al-Ghazali.

Internalization is the long-term process of consolidating and embedding one's own beliefs, attitudes, and values, when it comes to moral behavior. The accomplishment of this may involve the delib-erate use of psychoanalytical or behavioral methods. When chang-ing moral behavior, one is said to be "internalized" when a new set of beliefs, attitudes, and values replaces or habituates the desired behavior. For example, such internalization might take place fol-lowing religious conversion. ${ }^{18}$

Pembentukan moral, karakter atau internalisasi nilai atau penanaman afeksi tidak cukup hanya diajarkan lewat kognisi saja. Kognisi menurut Krathwohl hanya memberikan kontribusi yang kecil pada pembentukan afeksi. Aspek afeksi dalam penanamannya memerlukan praktek langsung, mereka perlu dibiasakan (babituated) tentang nilai-nilai tertentu yang akan ditanamkan. ${ }^{19}$

Seringkali aspek ini terlupakan oleh para pendidik dan ahli pendidikan. Pendidikan seringkali mengambil jalan instant sehingga secara otomatis meniadakan pembiasaan. Tradisi dan karakter dapat dibentuk melalui latihan dan pembiasaan. Ketika suatu praktek su-

\footnotetext{
${ }^{18}$ http://en.wikipedia.org/wiki//nternalization

${ }^{19}$ Krathwohl, David R. Taxonomy of Educational, hlm. 20.
} 
dah terbiasa dilakukan, berkat pembiasaan, maka akan menjadi habit bagi yang melakukannya kemudian akan menjadi ketagihan, dan pada waktunya menjadi tradisi yang sulit untuk ditinggalkan. ${ }^{20}$

Secara baganis menggambarkan bahwa perbuatan moral (moral action), yang ini merupakan produk dari pendidikan moral diperlukan suatu kebiasaan (babit), ${ }^{21}$ sebagai berikut:

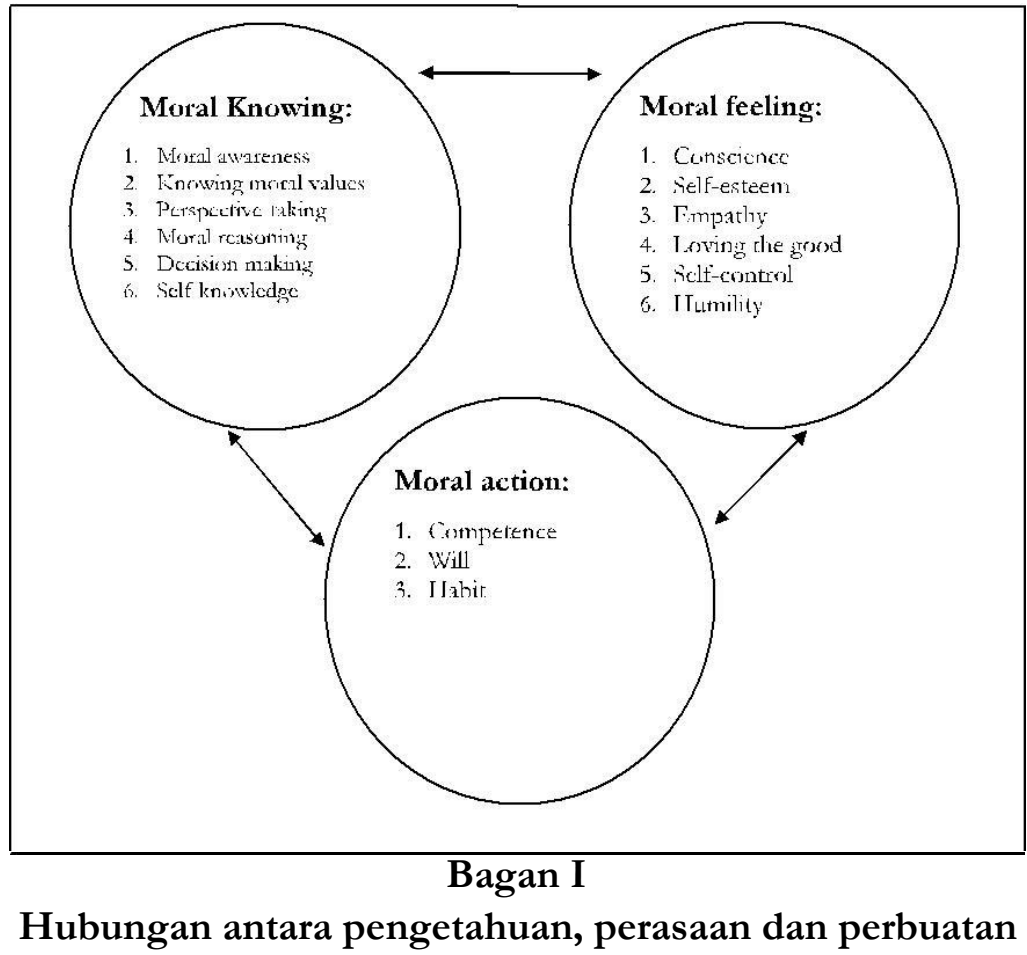

Dalam implementasi pembiasaan ini, diperlukan pendekatan integratif antara sekolah, masyarakat dan orang tua di lingkungan keluarga. Schecter dalam studinya memberikan pemahaman bahwa disposisi guru pada pelibatan orang tua di sekolah, memberikan keuntungan berkaitan dengan orientasi kurikulum untuk orang tua, membuka jalur komunikasi, membangun masyarakat, diversifikasi

${ }^{20}$ Azizy, A. Qodry, Pendidikan (Agama) untuk Membangun Etika Sosial: Mendidik Anak Sukses Masa Depan, Pandai dan Bermanfaat. (Semarang: Aneka Ilmu, 2002), hlm. 146

${ }^{21}$ Lickona, Thomas. Educating for Character..., hlm. 159. 
sumber, advokasi orang tua. Demikian juga Oladipo menyatakan bahwa "moral education was responsible for all. Because each child from birth belongs to significant group, so family members, friends, relatives, teachers and administrators play a major role in the formation of the character of each child". 22

Secara normatif, Islam menjelaskan dalam Ayat al-Quran surat al-Fushshilat/41 ayat 30 dan al-Ahqaf/46 ayat 13:

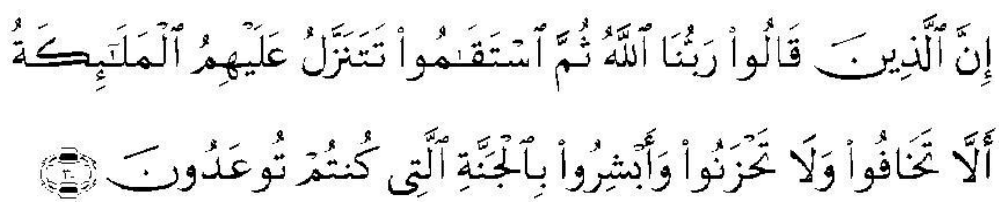

Sesungguhnya orang-orang yang mengatakan: "Tuhan kami ialah Allah" Kemudian mereka meneguhkan pendirian mereka, Maka malaikat akan turun kepada mereka dengan mengatakan: "Janganlah kamu takut dan janganlah merasa sedih; dan gembirakanlah mereka dengan jannah yang Telah dijanjikan Allah kepadamu" (QS al-Fushshilat/41: 30).

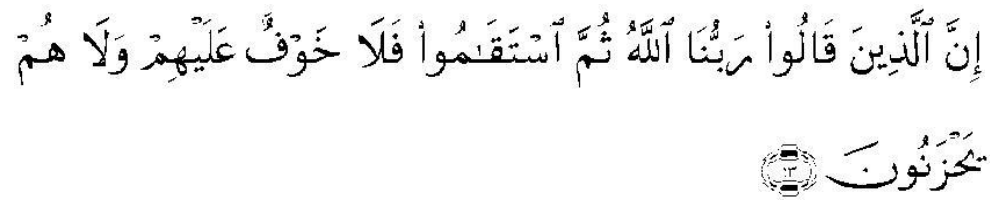

Sesungguhnya orang-orang yang mengatakan: "Tuhan kami ialah Allah", Kemudian mereka tetap istiqamah. Maka tidak ada kekhawatiran terhadap mereka dan mereka tiada (pula) berduka cita (QS al-Ahqaf/46: 13).

Dalam proses penanaman nilai-nilai akhlak tersebut memerlukan keteladanan (modelling). Sebab nilai-nilai (values) tidak bisa diajarkan, nilai-nilai hanya bisa dipraktekkan; maka sebagai pendidik, guru harus bisa menjadikan keteladanan bagi muridnya, sehingga pendidikan dilakukan dengan "aura pribadi”. Keteladanan menjadi aspek penting, terutama bagi anak-anak, untuk membiasakan hal-hal yang baik. Gerak gerik guru sebenarnya selalu diperhatikan oleh setiap murid. Tindak-tanduk, perilaku dan bahkan gaya guru mengajar

${ }^{22}$ Oladipo, S.E.. "Moral Education ..., hlm. 149 
pun akan sulit dihilangkan dalam ingatan setiap siswa. Lebih dari itu, karakter guru juga selalu diteropong dan sekaligus dijadikan cermin oleh murid-muridnya. Dalam kontek ini juga Mochtar Buchori me-nyatakan bahwa:

\section{"Men kan niet onderwijzen wat men weet, Men kan niet onderwijzen wat men wil, Men kan alleeen onderwijzen wat men is}

\section{Artinya:}

"Kita tidak dapat mengajarkan apa yang kita ketahui, Kita tidak dapat mengajarkan apa yang kita kehendaki, Kita hanya dapat mengajarkan apa yang memang ada dalam diri kita"

Dalam beberapa studi ditunjukkan bahwa perilaku pemimpin itu mempengaruhi kepada perilaku pengikutnya, apa style kepemimpinannya itu, transformational atau transaksional? Di antaranya adalah, dengan penelitian survey terhadap sejumlah besar responden ( $\mathrm{n}-672)$ dan eksperimen ( $\mathrm{n}=225)$, menunjukkan bahwa kepemimpinan transformational dan transactional itu membawa pengaruh positif terhadap identitas moral pengikutnya. Juga, transformational style memiliki pengaruh yang lebih besar daripada transactional style. Demikian juga, memang secara psiko-sosial, perkembangan individu anak banyak dibentuk melalui imitasi, identifikasi, sugesti, simpati, empati.

Secara historis, Muhammad sebagai nabi dan rasul memberikan evidensi empirik bahwa keberhasilan Muhammad dalam membentuk pribadi umat dikarenakan pembiasaan dan juga keteladanannya kepada pada sahabat.

Dan praktek tersebut ditegaskan dan diabadikan dalam alQuran bahwa Muhammad merupakan teladan (uswah hasanah) bagi umatnya (QS al-Ahzab/32: 21). 


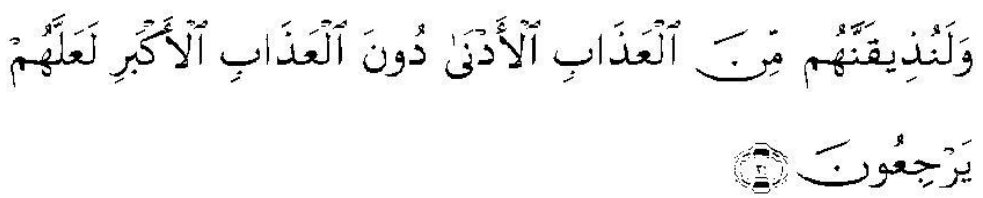

Sesungguhnya Telah ada pada (diri) Rasulullah itu suri teladan yang baik bagimu (yaitu) bagi orang yang mengharap (rahmat) Allah dan (kedatangan) hari kiamat dan dia banyak menyebut Allah (QS-al Ahzab/32: 21).

Senada dengan itu, Noddings juga menawarkan pernyataan bahwa ada beberapa cara untuk penanaman moral, yaitu dengan cara modelling, dialogue, practice, and confirmation.

1. Modelling, They are all activated within, and depend for their success on, the establishment of caring relations. Modeling is named as an important infl uence in almost every view of moral education, and Slote points out that a child may choose a person (or fi ctitious character) as a moral model either consciously or unconsciously.

2. Dialogue, The second component in moral education from the care perspective is dialogue. Genuine dialogue is open-ended at the outset, and it is weightier than mere conversation, although conversation can also contribute to moral education (Noddings, 1994). In dialogue, both parties speak, and both parties listen. They work their way sensitively toward the resolution of a problem. The role of carer and cared-for may shift as the dialogue proceeds, but in parent-child and teacher-student dialogues, the adult mainly acts as carer. The purpose of such dialogues is usually to identify needs, to learn what the cared-for is going through, or what the carer is aiming for, and then to work cooperatively on meeting the needs.

Dialogue within a caring relation is marked by attention to the other. Sometimes, if the topic is causing distress or threatens to become a heated argument, the carer will change the subject and 'pause to remind the other of her strengths, to reminisce, to explore, to express concern, to have a good laugh, ... Dialogue ... involves attention to [the cared-for], not just to the topic un- 
der discussion' (Noddings, 2002, 17). Even when dialogue does not result in a mutually acceptable solution - perhaps especially when it does not do so - it should end in a way that sustains the caring relation.

3. Practice, introduces a dimension that does not receive suffi cient attention when the emphasis is on induction. Good parents and teachers provide opportunities for children and students to practice caring. Of course, this practice involves the exercise of empathy or sympathy, and the parent or teacher watches to ensure that the interactions are rightly called caring. It is not simply a matter of correcting uncaring ehavior, although that is certainly part of the teacher's task; induction is clearly important in doing this. But the good teacher also takes note of kind and helpful behaviors and compliments the child who demonstrates care.

4. Confi rmation, might be thought of as a positive variant of induction. Moral educators not only draw children's attention to the pain they have caused; in many situations, they also credit children with motives that are morally better than a disappoint-ing act suggests. A teacher may honestly remind a boy who has cheated on a test that she understands his desire to please his father with good grades. She acknowledges that he had an ad-mirable motive. But then the teacher must engage in dialogue to help the boy see that his act did not measure up to his motive. Confirmation points a person toward a better self, and it is itself a beautiful moral act.

Maka bila Darni M. Daud, Rektor Universitas Syiah Kuala dalam pertemuan tahunan Forum Rektor Indonesia di Universitas Haluoleo, menyatakan bahwa "Pendidikan karakter tidak berhasil jika hanya retorika. Suksesnya pendidikan karakter justru butuh keteladanan. Kita sering membicarakan karakter bangsa, tetapi hanya sebatas retorika. Tidak sedikitpun tercermin dalam kehidupan sehari-hari, terutama dari pemimpin bangsa. Padahal, pendidikan karakter itu efektif dengan keteladanan", adalah dalam kontek tersebut.

Pembiasaan dan keteladanan untuk "hal-hal yang baik" ini memerlukan waktu yang relatif lama. Artinya, penanaman nilai-nilai (values) keagamaan memerlukan membutuhkan waktu yang panjang 
untuk sampai pada "karakterisasi" (characterization), di mana suatu value sudah menjadi karakter (kepribadian) dari seseorang.

Senada dengan itu, Rachmawati mengemukakan bahwa pembentukan budi pekerti melalui beberapa tahapan, yakni: (a) Mempersiapkan fondasi budi pekerti luhur (b) Pembelajaran melalui keteladanan (modelling) (c) Pembelajaran melalui pembiasaan (d) Pembinaan pengetahuan; yang secara skematis, bisa digambarkan sebagai berikut:

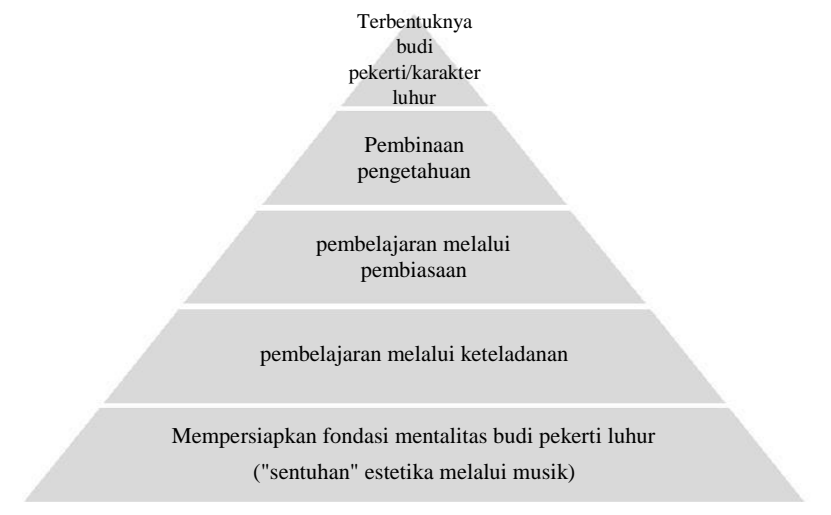

Berbeda dengan itu, ada lima fase yang harus dilalui yang diawali dengan pengetahuan terlebih dahulu, yakni: knowing (mengetahui nilai), comprehending (memahami nilai- nilai), accepting (menerima nilai-nilai), internalizing (menjadikan nilai sebagai sikap dan keyakinan), implementing (mengamalkan nilai-nilai). Senada dengan ini, David R. Krathwohl juga mengemukakan bahwa proses itu meliputi lima tahap, yakni receiving (menyimak), responding (menanggapi), valuing (memberi nilai), organization (mengorganisasikan nilai), characterization (karakterisasi nilai). ${ }^{23}$

Karenanya pendekatan yang bisa dipertimbangkan berkaitan dengan afeksi ini yaitu: (1) evocation (2) inculcation (3) moral reasoning (4) value clarification (5) value analysis (6) moral awareness (7) commitment approach. 24

${ }^{23}$ Krathwohl, David R. Taxonomy of Educational.., hlm. 35.

${ }^{24}$ Rachman, Maman. "Reposisi, Re-Evaluasi dan Rede $\square$ nisi Pendidikan Nilai bagi Generasi Muda Bangsa", Jurnal Pendidikan dan Kebudayaan. (Jakarta: Balitbang Depdiknas, Maret 2001), Nomor 028, hlm. 5. 
Secara formal di sekolah, ada beberapa model pembelajaran afektif sesuai dengan kondisinya, yaitu model konsiderasi, pembentukan rasional, klarifi kasi nilai, pengembangan moral kognitif, model nondirektif:

1. Model Konsiderasi. Manusia seringkali bersifat egoistis, lebih memperhatikan, mementingkan, dan sibuk dan sibuk mengurusi dirinya sendiri. Melalui penggunaan model konsiderasi (consider-ation mode) siswa didorong untuk lebih peduli, lebih memperha-tikan orang lain, sehingga mereka dapat bergaul, bekerja sama, dan hidup secara harmonis dengan orang lain. Langkah-langkah pembelajaran konsiderasi:

a. menghadapkan siswa pada situasi yang mengandung konsiderasi

b. meminta siswa menganalisis situasi untuk menemukan isyarat-isyarat yang tersembunyi berkenaan dengan perasaan, kebutuhan dan kepentingan orang lain

c. siswa menuliskan responsnya masing-masing

d. siswa menganalisis respons siswa lain

e. mengajak siswa melihat konsekuesi dari tiap tindakannya

f. meminta siswa untuk menentukan pilihannya sendiri

2. Model pembentukan rasional. Dalam kehidupannya, orang berpegang pada nilai-nilai sebagai standar bagi segala aktivitasnya. Nilai-nilai ini ada yang tersembunyi, dan ada pula yang dapat dinyatakan secara eksplisit. Nilai juga bersifat multidimensional, ada yang relatif dan ada yang absolut. Model pembentukan rasional (rational building model) bertujuan mengembangkan kematangan pemikiran tentang nilai-nilai. Langkah-langkah pembelajaran rasional:

a. menigidentifikasi situasi dimana ada ketidakserasian atau penyimpangan tindakan

b. menghimpun informasi tambahan

c. menganalisis situasi dengan berpegang pada norma, prinsip atau ketentuan-ketentuan yang berlaku dalam masyarakat

d. mencari alternatif tindakan dengan memikirkan akibat- 
akibatnya,

e. mengambil keputusan dengan berpegang pada prinsip atau ketentuen-ketentuan legal dalam masyarakat

3. Klarifikasi nilai. Setiap orang memiliki sejumlah nilai, baik yang jelas atau terselubung, disadari atau tidak. Klarifi kasi nilai (value clarification model) merupakan pendekatan mengajar dengan menggunakan pertanyaan atau proses menilai (valuing process) dan membantu siswa menguasai keterampilan menilai dalam bidang kehidupan yang kaya nilai. Penggunaan model ini bertujuan, agar para siwa menyadari nilai-nilai yang mereka miliki, memunculkan dan merefleksikannya, sehingga para siswa memiliki keterampilan proses menilai. Langkah-langkah pembelajaran klasifikasi nilai:

a. pemilihan: para siswa mengadakan pemilihan tindakan secara bebas, dari sejumlah alternatif tindakan mempertimbangkan kebaikan dan akibat-akibatnya

b. mengharagai pemilihan: siswa menghargai pilihannya serta memperkuat-mempertegas pilihannya

c. berbuat: siswa melakukan perbuatan yang berkaitan dengan pilihannya, mengulanginya pada hal lainnya

4. Pengembangan moral kognitif. Perkembangan moral manusia berlangsung melalui restrukturalisasi atau reorganisasi kognitif, yang yang berlangsung secara berangsur melalui tahap pra-konvensi, konvensi dan pasca konvensi. Model ini bertujuan membantu siswa mengembangkan kemampauan mempertimbangkan nilai moral secara kognitif. Langkah-langkah pembelajaran moral kognitif:

a. menghadapkan siswa pada suatu situasi yang mengandung dilema moral atau pertentangan nilai

b. siswa diminta memilih salah satu tindakan yang mengandung nilai moral tertentu

c. siswa diminta mendiskusikan/ menganalisis kebaikan dan kejelekannya 
d. siswa didorong untuk mencari tindakan-tindakan yang lebih baik

e. siswa menerapkan tindakan dalam segi lain.

5. Model nondirektif. Para siswa memiliki potensi dan kemampuan untuk berkembang sendiri. Perkembangan pribadi yang utuh berlangsung dalam suasana permisif dan kondusif. Guru hendaknya menghargai potensi dan kemampuan siswa dan berperan sebagai fasilitator/konselor dalam pengembangan kepribadian siswa. Penggunaan model ini bertujuan membantu siswa mengaktualisasikan dirinya. Langkah-langkah pembelajaran nondirekif:

a. menciptakan sesuatu yang permisif melalui ekspresi bebas,

b. pengungkapan siswa mengemukakan perasaan, pemikiran dan masalah-masalah yang dihadapinya,guru menerima dan memberikan klarifi kasi,

c. pengembangan pemahaman (insight), siswa mendiskusikan masalah, guru memberrikan dorongan,

d. perencanaan dan penentuan keputusan, siswa merencanakan dan menentukan keputusan, guru memberikan klarifikasi,

e. integrasi, siswa memperoleh pemahaman lebih luas dan mengembangkan kegiatan-kegiatan positif.

\section{Kesimpulan}

Moralitas adalah sifat moral atau keseluruhan asas dan nilai yang berkenaan dengan baik dan buruk. Akhlak atau Moralitas Islam (Islamic morality) berperan sebagai pengatur dan petunjuk bagi manusia dalam berperilaku agar dapat dikategorikan sebagai manusia yang baik dan dapat menghindari perilaku yang buruk. Untuk membentuk manusia yang memiliki moral baik (good moral person) bukanlah sesuatu yang tiba-tiba. Ia memerlukan suatu proses panjang yang memerlukan tahap-tahap, ia membutuhkan suatu kondisi yang 
memungkinkan seorang individu berperilaku sebagai sosok yang memiliki moral yang diharapkan (moral action).

Karenanya, ia memerlukan suatu pembiasaan (babituation) yang dalam pembiasaan itu secara implisit terdapat adanya keteladanan (modelling). Karena itu diperlukan kerjasama secara integratif dari semua komponen baik di sekolah, keluarga maupun masyarakat untuk menciptakan lingkungan yang mampu membiasakan perilaku anak. Secara formal, dalam proses pembelajaran bisa dipertimbangkan beberapa model pembelajaran yang bisa dipilih sesuai dengan situasi yang melingkupinya, yaitu: model konsiderasi, pembentukan rasional, klarifikasi nilai, pengembangan moral kognitif, model nondirektif. 


\section{DAFTAR PUSTAKA}

Azizy, A. Qodry, 2002, Pendidikan (Agama) untuk. Membangun Etika Sosial: Mendidik Anak Sukses Masa Depan, Pandai dan Bermanfaat. Semarang: Aneka Ilmu.

Azra, Azyumardi, 2002, Paradigma Baru Pendidikan Nasional: Rekonstruksi dan Demokratisasi. Jakarta: Kompas.

Bertens, Kees, 2002, Etika, Jakarta: Gramedia Pustaka Utama.

Gerungan, W.A. 1998, Psikologi Sosial. Jakarta: Rajawali Pers.

Hadjar, Ibnu, "Evaluasi Hasil Belajar Afektif Pendidikan Agama: Problem Konseptual dan Pengukuran", Pidato Pengukuhan Guru Besar dalam Ilmu Evaluasi Pendidikan pada Fakultas Tarbiyah IAIN Walisongo, tgl. 4 Maret 2006.

Keraf, Sony, 1991, Etika Bisnis. Yogjakarta: Kanisius.

Krathwohl, David R. 1973, Taxonomy of Educational Objective Book II: Affective Domain. London: Longman Group.

Lickona, Thomas, 1992, Educating for Character: How Our Schools Can Teach Respect and Responsibilty. New York: Bantam Book.

Mas'ud, Abdurrahman, 2002, Menggagas Format Pendidikan Non Dikotomik: Humanisme Religius sebagai Paradigma Pendidikan Islam. Yogjakarta: Gama Media. 
Mubarak, Zakky, dkk. , 2008, Manusia, Akblak, Budi Pekerti dan Masyarakat. Depok: Lembaga Penerbit FE UI.

Mudhofir, Ali et al. 1996, Filsafat Ilmu. Yogjakarta: Liberty.

Noddings, Neil, 2010, "Moral Education and Caring" dalam Journal Theory and Research in Education, 8 (2), 145-151.

Oladipo, S.E., 2009, "Moral Education of the Child: Whose Responsibility?”, J Sec Sei, 20(2), pp. 149-156.

Rachman, Maman. Maret 2001, "Reposisi, Re-Evaluasi dan Redefi nisi Pendidikan Nilai bagi Generasi Muda Bangsa", Jurnal Pendidikan dan Kebudayaan. Jakarta: Balitbang Depdiknas, Nomor 028.

Ramayulis, 2005, Metodologi Pendidikan Agama Islam. Jakarta: kalam Mulia.

Suryabrata, Sumadi, 1993, Psikologi Pendidikan. Jakarta: Rajawali Pers.

Umi Latifah, Siti. 2011, "Pola-pola Metode keteladanan untuk Penanaman Akhlak Peserta Didik di SD negeri Pengkol Godean Sleman Yogjakarta", hasil penelitian, Fakultas Tarbiyah UIN Sunan Kalijaga.

Velasques, Manuel G., 2005, Etika Bisnis, Konsep dan Kasus Business Ethics, Concepts and Cases, terj. Ana Purwaningsih dkk, Yogjakarta: Kanisius.

Zubaedi, 2009, "Memperkuat Dimensi Pendidikan Moral: Kata Pengantar" dalam Mawardi Lubis. Evaluasi Pendidikan Nilai. Yogjakarta: Pustaka Pelajar. 
Supangat Rohani 
